\title{
Calcium carbonate precipitation induced by the growth of the marine cyanobacterium Trichodesmium
}

\author{
Sven A. Kranz, ${ }^{\mathrm{a},{ }^{*}}$ Dieter Wolf-Gladrow, ${ }^{\mathrm{a}}$ Gernot Nehrke, ${ }^{\mathrm{a}}$ Gerald Langer, ${ }^{\mathrm{b}}$ and Björn Rosta
}

a Alfred Wegener Institute for Polar and Marine Research, Bremerhaven, Germany

b Institut de Ciència i Tecnologia Ambientals, Autonomous University of Barcelona (UAB), Bellaterra, Spain

\begin{abstract}
In this laboratory study, we monitored the buildup of biomass and concomitant shift in seawater carbonate chemistry over the course of a Trichodesmium bloom under different phosphorus (P) availability. During exponential growth, dissolved inorganic carbon (DIC) decreased, while $\mathrm{pH}$ increased until maximum cell densities were reached. Once $\mathrm{P}$ became depleted, DIC decreased even further and total alkalinity (TA) dropped, accompanied by precipitation of aragonite. Under P-replete conditions, DIC increased and TA remained constant in the postbloom phase. A diffusion-reaction model was employed to estimate changes in carbonate chemistry of the diffusive boundary layer. This study demonstrates that Trichodesmium can induce precipitation of aragonite from seawater and further provides possible explanations about underlying mechanisms.
\end{abstract}

Phytoplankton plays a vital role in geochemical cycling of biogenic elements and has influenced Earth's climate over geological time scales. These photoautotrophic organisms fix carbon dioxide $\left(\mathrm{CO}_{2}\right)$ in the upper mixed layer of the ocean and subsequently drive the vertical export of particulate organic carbon (POC). In the water column, remineralization and respiration releases organically bound $\mathrm{CO}_{2}$, which then accumulates in deeper layers. This process, termed "organic carbon pump," causes a net drawdown of $\mathrm{CO}_{2}$ from the atmosphere into the ocean. Besides organic matter, some marine organisms also produce calcium carbonate $\left(\mathrm{CaCO}_{3}\right)$, mostly in the form of calcite or aragonite, two polymorphs of $\mathrm{CaCO}_{3}$ with different lattice structures and solubility properties. Precipitation of $\mathrm{CaCO}_{3}$ by various groups of organisms provides a $\mathrm{CO}_{2}$ source for the atmosphere. This counterintuitive effect of the so-called carbonate pump is caused by consumption of dissolved inorganic carbon (DIC) and total alkalinity (TA) in a $1: 2$ ratio during the process of calcification (Zeebe and Wolf-Gladrow 2007).

Marine productivity is typically driven by diatoms, coccolithophores, dinoflagellates, and cyanobacteria. As the most ancient group, cyanobacteria were responsible for the original oxidization of the Earth's atmosphere and dominated elemental cycles over geological time scales (Des Marais 2000). In the Cretaceous, this group was also known to play an important role in the buildup of immense carbonate sediments (Riding 2006). Today, $\mathrm{CaCO}_{3}$ production by cyanobacteria seems to be more or less restricted to specific environments like hard-water lakes, stromatolites, or biological crusts (Pentecost and Riding 1986). In contemporary oceans, cyanobacteria are considered mostly in view of their ability to provide new nitrogen by $\mathrm{N}_{2}$ fixation.

The bloom-forming filamentous diazotroph Trichodesmium plays a vital role for primary productivity in the tropical and subtropical oceans (Capone et al. 2005;

\footnotetext{
*Corresponding author: Sven.kranz@awi.de
}

Mulholland et al. 2006). In contrast to nondiazotrophic species, the development of a Trichodesmium bloom is therefore often controlled by the availability of phosphorus (P) and/or iron rather than "reactive N" (e.g., nitrate, nitrite, ammonium, urea). As described in several studies on phytoplankton bloom dynamics, the buildup of biomass is typically accompanied by a decrease in DIC and an increase in pH (Holligan et al. 1993; Arrigo et al. 1999). To our knowledge, there are no data on changes in carbonate chemistry over the course of a Trichodesmium bloom. Yet high biomasses observed in Trichodesmium blooms ( $\mathrm{La}$ Roche and Breitbarth 2005) imply large alteration in the carbonate chemistry.

In this study, we investigated the bloom development of Trichodesmium under different $\mathrm{P}$ availability and monitored corresponding changes in carbonate chemistry. In addition to a strong shift in carbonate chemistry, $\mathrm{CaCO}_{3}$ was formed under P-deplete conditions. Possible explanations for this precipitation process are provided.

\section{Methods}

Experimental setup - Cultures of Trichodesmium erythraeum IMS101 (CCMP1985) were grown at $26^{\circ} \mathrm{C}$ in $0.2-\mu \mathrm{m}$-filtered artificial seawater (based on YBCII media; Chen et al. 1996; Table 1). Light intensity of $200 \mu \mathrm{mol}$ photons $\mathrm{m}^{-2} \mathrm{~s}^{-1}$ was provided in a $12: 12$-h light: dark cycle. A preculture of Trichodesmium was grown under these conditions in two 2-L borosilicate bottles for $20 \mathrm{~d}$. Cells were kept at low cell densities (Chl $a$ concentration $<$ $0.1 \mathrm{mg} \mathrm{L}^{-1}$ ), and $\mathrm{P}$ concentration ranged between 4 and $6 \mu \mathrm{mol} \mathrm{L}{ }^{-1}$. Experiments were carried out in sterile $20-\mathrm{L}$ polycarbonate Nalgene bottles. To keep cells in suspension, bottles were placed on an orbital shaker. The headspace was continuously exchanged via a membrane pump with $0.2-\mu \mathrm{m}$-filtered ambient air $\left(\sim 37.5 \mathrm{~Pa} \mathrm{pCO}_{2}\right)$. For each treatment, cells from the precultures were inoculated into $15 \mathrm{~L}$ of culture media, and $\mathrm{P}$ concentration was adjusted to $6 \mu \mathrm{mol} \mathrm{L}^{-1}$. In one treatment, the P concentration was kept 
Table 1. Composition of the artificial seawater (modified YBCII media).

\begin{tabular}{lclc}
\hline \hline Chemical & Amount $\left(\mathrm{mmol} \mathrm{L}^{-1}\right)$ & \multicolumn{1}{c}{ Chemical } & Amount $\left.(\mu \mathrm{mol} \mathrm{L})^{-1}\right)$ \\
\hline $\mathrm{NaCl}$ & 420 & $\mathrm{FeCl}_{3}$ & 0.41 \\
$\mathrm{KCl}$ & 10 & $\mathrm{Na}_{2}$-EDTA & 2 \\
$\mathrm{MgCl}_{2}$ & 20 & Biotin & 0.002 \\
$\mathrm{CaCl}_{2}$ & 10 & Vitamin $\mathrm{B} 12$ & 0.004 \\
$\mathrm{MgSO}_{4}$ & 25 & $\mathrm{Thiamine}^{\mathrm{HCl}}$ & 0.3 \\
$\mathrm{KBr}_{\mathrm{H}} \mathrm{BO}_{3}$ & 1 & $\mathrm{MnCl}_{2}$ & 0.02 \\
$\mathrm{SrCl}_{2}$ & 0.58 & $\mathrm{ZnSO}_{4}$ & 0.004 \\
$\mathrm{NaF}$ & 0.07 & $\mathrm{CoCl}_{2}$ & 0.003 \\
$\mathrm{LiCl}$ & 0.07 & $\mathrm{Na}_{2} \mathrm{MoO}_{4}$ & 0.011 \\
$\mathrm{NaHCO}$ & 0.03 & $\mathrm{CuSO}_{4}$ & 0.001 \\
\hline
\end{tabular}

between 2.5 and $6 \mu \mathrm{mol} \mathrm{PO}_{4}^{3-}$ by repeated additions of a $1 \mathrm{~mol} \mathrm{~L}^{-1} \mathrm{PO}_{4}^{3-}$ stock solution ( $\mathrm{P}$ replete), while in the other treatment, $\mathrm{P}$ was allowed to be fully consumed by the cells ( $\mathrm{P}$ deplete). Both treatments were run in duplicate incubations.

Subsamples from these incubations were taken every day to measure cell density and chemical composition of the media. Samples for inorganic phosphorus $(5 \mathrm{~mL})$ were measured colorimetrically on a daily basis using a continuous flow analyzer (Evolution III; Alliance Instruments). TA samples $(80 \mathrm{~mL})$ were filtered through glassfiber filters (GFF; nominal pore size $\sim 0.6 \mu \mathrm{m}$ ) and stored in borosilicate bottles at room temperature until potentiometric titration with an average precision of $\pm 7 \mu \mathrm{mol}$ $\mathrm{kg}^{-1}$. TA was calculated from linear Gran Plots (Gran 1952). DIC samples $(5 \mathrm{~mL})$ were sterile filtered (cellulose acetate filters, pore size $0.2 \mu \mathrm{m}$ ) and stored in borosilicate flasks without headspace at $4{ }^{\circ} \mathrm{C}$. DIC was measured using an Technicon TRAACS 800 (Stoll et al. 2001) with a precision of $\pm 5 \mu \mathrm{mol} \mathrm{kg} \mathrm{kg}^{-1}$. TA and DIC measurements were calibrated using certified reference seawater standards (supplied by Dr. Andrew Dickson, Scripps Institution of Oceanography). Salinity was determined by measuring apparent electrical conductivity (WTW Cond330i; TetraCon 325). Conductivity was subsequently converted to salinity using an inbuilt algorithm. The carbonate system $\left(\mathrm{pH}_{\text {tot }} ; \Omega_{\mathrm{Ar}}\right)$ was calculated from TA, DIC, temperature, salinity, and phosphate concentration using CO2Sys (Lewis and Wallace 1998). Equilibrium constants of Mehrbach et al. (1973) refitted by Dickson and Millero (1987) were chosen.

For the analysis of chlorophyll a (Chl a) and POC, sampling volumes were adjusted to biomass, ranging between $500 \mathrm{~mL}$ (beginning of experiment) and $5 \mathrm{~mL}$ (end of experiment). Chl $a$ samples were filtered onto GFF and stored at $-80^{\circ} \mathrm{C}$. Chl $a$ was subsequently extracted in acetone (overnight in darkness at $4^{\circ} \mathrm{C}$ ) and determined with a fluorometer (Turner Designs) by measuring nonacidified and acidified fluorescence. Cell numbers were calculated on the basis of the Chl $a$ quotas (Kranz et al. 2009). Samples for POC were filtered onto precombusted $\left(500^{\circ} \mathrm{C} ; 9 \mathrm{~h}\right) \mathrm{GFF}$ and stored in precombusted $\left(500^{\circ} \mathrm{C} ; 9 \mathrm{~h}\right)$ petri dishes at $-20^{\circ} \mathrm{C}$. Prior to analysis, filters were treated with $200 \mu \mathrm{L}$ $\mathrm{HCl}\left(0.1 \mathrm{~mol} \mathrm{\textrm {L } ^ { - 1 } )}\right.$ to remove all inorganic carbon. Subsequently, POC was measured on a mass spectrometer
(ANCA-SL 2020) with a precision of $\sim 1 \%$ of the total carbon amount (Anders Ohlsson and Wallmark 1999).

Growth rates $(\mu)$ within the exponential growth phase were calculated on the basis of $\mathrm{Chl} a$ concentration according to

$$
\mu\left(\mathrm{d}^{-1}\right)=\frac{\ln \left(N_{1}\right)-\ln \left(N_{0}\right)}{\Delta t}
$$

where $N_{0}$ and $N_{1}$ are concentration of Chl $a$ at time $t_{0}$ and $t_{1}$, respectively, and $\Delta t$ is the time between sampling intervals in days.

At the end of the postbloom phase, the particulate fraction of the residual medium $(\sim 6 \mathrm{~L})$ was harvested via centrifugation $(5000 \times g, 10 \mathrm{~min})$. Scanning electron microscopy (SEM; Philips XL-30) was used to identify the structure of the particles. Aliquots of the solid phase were placed onto polycarbonate filters (Nucleopore; pore size $0.2 \mu \mathrm{m}$ ), dried for $3 \mathrm{~h}$ at $50^{\circ} \mathrm{C}$, and stored in a desiccator. Filters were finally sputter coated with goldpalladium and analyzed by means of SEM. For phase identification of the inorganic particles, a confocal Raman microscope (WITec) was used, having a diode laser $(785 \mathrm{~nm})$ with an excitation energy of $20 \mathrm{~mW}$ at the sample surface (determined with a Coherent LaserCheck powermeter) and a Nikon $100 \mathrm{X}$ (NA 0.95) objective. Prior to the measurements, samples were washed in acetone $(90 \%)$ to remove organics and minimize the background noise. Raman spectra were determined at 20 different positions chosen randomly across the precipitate.

To estimate the carbonate chemistry in the microenvironment of a Trichodesmium aggregate, a diffusionreaction model has been applied (Wolf-Gladrow and Riebesell 1997). Bulk seawater carbonate chemistry measured at day 13 was chosen as model input. Carbon fixation rates used in the model were approximated from growth rates $\left(0.31 \mathrm{~d}^{-1}\right)$ and POC quotas $\left(5 \mathrm{pmol}\right.$ cell $\left.{ }^{-1}\right)$ in the late exponential phase. $\mathrm{HCO}_{3}^{-}$contributions on total $\mathrm{C}$ uptake of $80 \%$ were taken from Kranz et al. (2009). For model calculations, a spherical aggregate (diameter $700 \mu \mathrm{m}$ ) with 15,000 cells was assumed.

\section{Results}

At the beginning of the experiment, $\mathrm{Chl} a$ concentrations ranged between 0.6 and $1.4 \mu \mathrm{g} \mathrm{Chl} a \mathrm{~L}^{-1}$. Cell growth was 


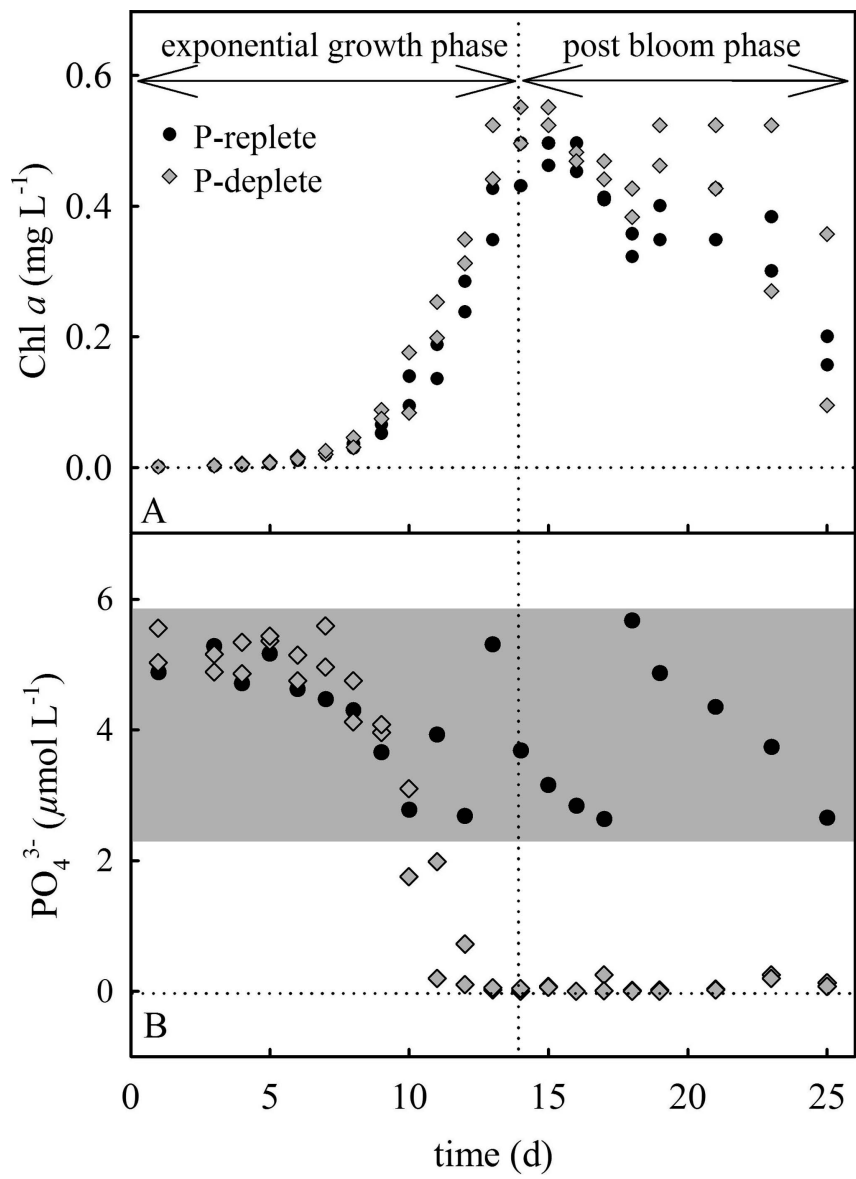

Fig. 1. Changes in concentrations of (A) Chl $a$ and (B) $\mathrm{PO}_{4}^{3-}$ over the course of a bloom. Gray diamonds present the P-deplete and black circles the P-replete cultures. The vertical dotted line represents the transition phase between exponential and postbloom phase. The gray area represents the range of $\mathrm{PO}_{4}^{3-}$ concentrations in the P-replete culture.

monitored over the duration of $25 \mathrm{~d}$. After inoculation, cells did not exhibit a lag phase and started to grow exponentially for 13 to $14 \mathrm{~d}$ before reaching maximum $\mathrm{Chl}$ $a$ concentrations, followed by a postbloom phase (Fig. 1A). In one treatment, cells were allowed to consume $\mathrm{P}$ entirely (P deplete; Fig. 1B), reaching $\mathrm{PO}_{4}^{3-}$ levels below $0.1 \mu \mathrm{mol} \mathrm{L}-1$ after day 11 . In the other treatment, $\mathrm{PO}_{4}^{3-}$ concentrations were maintained between 2.5 and $6 \mu \mathrm{mol} \mathrm{L}^{-1}$ (P replete; Fig. 1B). Specific growth rates during the midexponential phase, determined by changes in Chl $a$ concentration (Fig. 1A), were similar for all cultures and ranged between 0.51 and $0.58 \mathrm{~d}^{-1}$. Maximum Chl $a$ concentrations were $0.54 \pm 0.02 \mathrm{mg} \mathrm{L}^{-1}$ in the P-deplete cultures and $0.48 \pm 0.03 \mathrm{mg} \mathrm{L}^{-1}$ in the P-replete cultures.

The carbonate chemistry showed similar patterns during early and midexponential growth phases in both P-replete and P-deplete cultures but started to deviate strongly in terms of DIC and TA at the end of the exponential phase (days 13 and 14; Fig. 2A,B). In the P-replete cultures, the DIC decreased from an initial concentration of 2150 $\mu \mathrm{mol} \mathrm{kg}-1$ to a minimum of about $1500 \mu \mathrm{mol} \mathrm{kg}^{-1}$ at the end of the exponential phase (Fig. 2A). During the postbloom phase, DIC increased again to values slightly lower than initial concentrations. The $\mathrm{pH}_{\text {tot }}$ increased with increasing cell densities, from initial values of 8.0 up to 8.81 (days 13-15; Fig. 2C). A decline in $\mathrm{pH}$ was observed during the postbloom phase, reaching values between 8.15 and 8.30 (Fig. 2C). TA remained relatively constant with a mean of $2447 \pm 16 \mu \mathrm{mol} \mathrm{kg} \mathrm{kg}^{-1}$ over the duration of the experiment (Fig. 2B). The calculated aragonite saturation state $\left(\Omega_{\mathrm{Ar}}=\left[\mathrm{Ca}^{2+}\right]\left[\mathrm{CO}_{3}^{2-}\right] /\right.$ solubility product of aragonite $)$ increased with increasing $\mathrm{pH}$ and decreasing DIC from initial values of $3.3 \pm 0.0$ up to $9.9 \pm 0.2$ (Fig. 2D).

In the P-deplete cultures, DIC decreased from initial concentrations of $2160 \mu \mathrm{mol} \mathrm{kg}-1$ to about $1000 \mu \mathrm{mol} \mathrm{kg}-1$, much lower than in the P-replete cultures, and values remained low until the end of the experiment (Fig. 2A). The $\mathrm{pH}_{\text {tot }}$ increased from initial values of 7.95 to 8.76 (on days 13 and 14) with a subsequent decline to values of about 7.90 (Fig. 2C). TA values remained relatively constant at $2447 \pm 12 \mu \mathrm{mol} \mathrm{kg}-1$ until the transition to the postbloom phase, when TA started to drop quickly and leveled off to about $1400 \mu \mathrm{mol} \mathrm{kg} \mathrm{kg}^{-1}$ (Fig. 2B). The calculated $\Omega_{\mathrm{Ar}}$ increased from initial $3.1 \pm 0.2$ to about $9.1 \pm 0.6$ (Fig. 2D). Two to $3 \mathrm{~d}$ after TA dropped in the Pdeplete culture, white precipitates were observed, which were sampled and analyzed at the end of the experiment.

The precipitate was investigated by means of SEM, showing particles that can be described best as aggregates of fibers having a length of about $20 \mu \mathrm{m}$ (Fig. 3A,B). The Raman spectra (Fig. 3C) of a sample and two references (calcite and aragonite) show the typical vibration modes $v_{1}$ $\left(1085 \mathrm{~cm}^{-1}\right.$ calcite and aragonite) and $v_{4}\left(711 \mathrm{~cm}^{-1}\right.$ calcite and $705 \mathrm{~cm}^{-1}$ aragonite) for $\mathrm{CO}_{3}^{2-}$ in a crystal lattice (Behrens et al. 1995). The precipitate can unambiguously be identified as aragonite using the lattice vibrations between 100 and $400 \mathrm{~cm}^{-1}$ wave numbers. Both calcite and aragonite show a strong peak at $\sim 153 \mathrm{~cm}^{-1}\left(155 \mathrm{~cm}^{-1}\right.$ calcite and $152 \mathrm{~cm}^{-1}$ aragonite) but show unique peaks at $282 \mathrm{~cm}^{-1}$ (calcite) and $206 \mathrm{~cm}^{-1}$ (aragonite). Raman spectra determined at 20 different positions chosen randomly across the precipitate showed no other carbonate phase than aragonite to be present. No Raman spectra analysis could be performed on the P-deplete cultures, as inorganic precipitates were not observed in this treatment.

Model results for the carbonate chemistry in the diffusive boundary layer of a Trichodesmium aggregate indicate a strong deviation in $\mathrm{pH}, \Omega_{\mathrm{Ar}}$, as well as DIC from the measured bulk values (Fig. 4). For the applied conditions (day 13), an increase in $\mathrm{pH}$ by 0.12 units and $\Omega_{\mathrm{Ar}}$ by 1 unit was observed, while DIC decreased by $\sim 100 \mu \mathrm{mol} \mathrm{kg}^{-1}$ toward the aggregate surface.

\section{Discussion}

Bloom events by Trichodesmium are often associated with highly stratified waters (Gianesella-Galvao et al. 1995; Siqueira et al. 2006) and low inorganic nutrient availability (Capone and Carpenter 1982), conditions that were mimicked in our laboratory study. The pattern and rate in the buildup of biomass (Fig. 1A) is consistent with the 


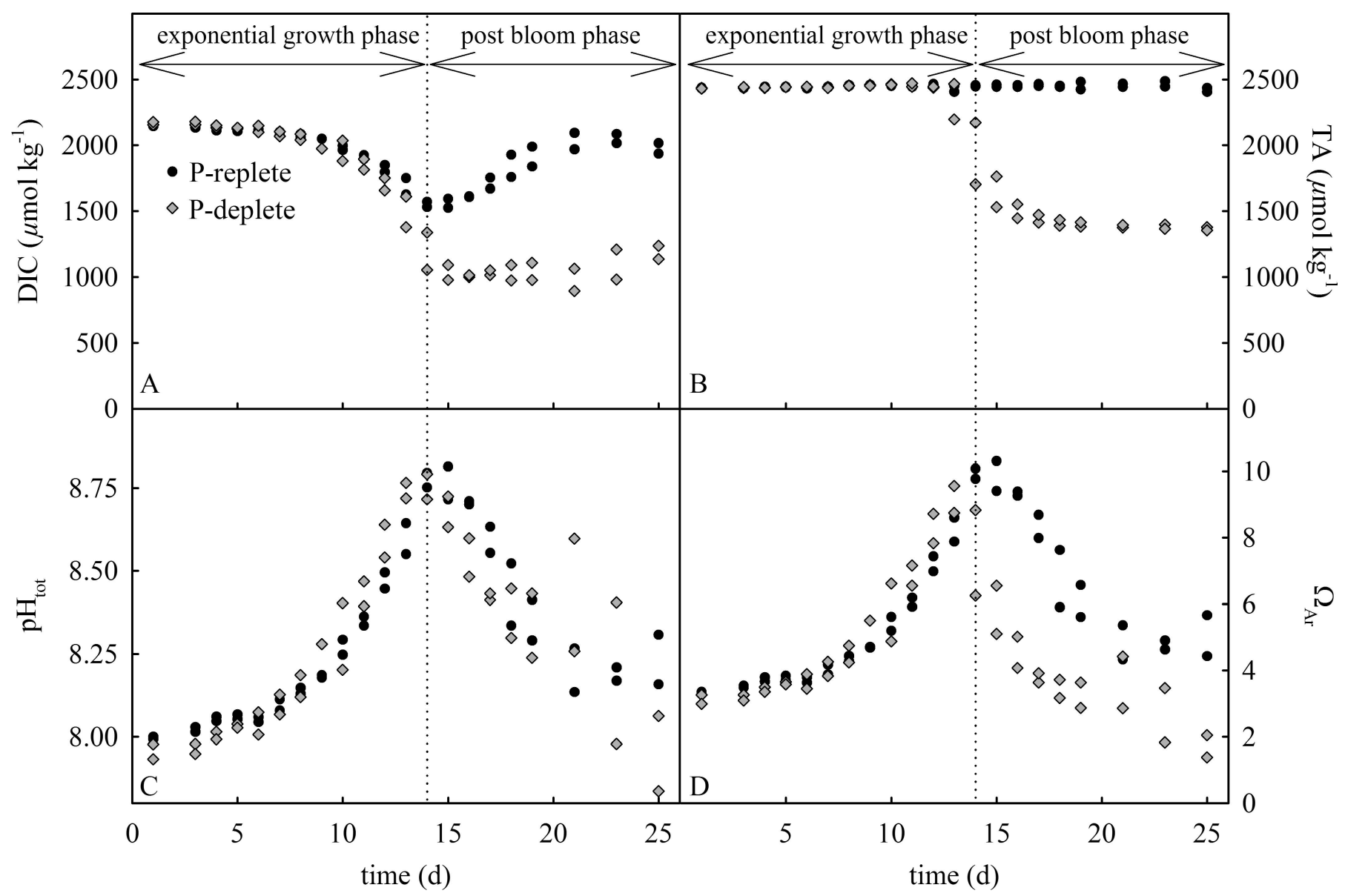

Fig. 2. Changes in (A) DIC, (B) TA, (C) $\mathrm{pH}_{\text {tot }}$, and (D) $\Omega_{\mathrm{Ar}}$ over the course of a bloom. Gray diamonds present the P-deplete and black circles the P-replete cultures. The vertical dotted line represents the transition phase between exponential and postbloom phase.

findings of previous studies on bloom dynamics of Trichodesmium (Berman-Frank et al. 2004; La Roche and Breitbarth 2005). Maximum cell densities obtained in this study were around $5.5 \times 10^{9}$ cells $\mathrm{L}^{-1}$, which is within the range of cell concentrations reported for blooms in the ocean (up to $6.6 \times 10^{9}$; La Roche and Breitbarth 2005). The observed termination of the bloom might be explained by high pH (Hansen et al. 2007) or oxidative stress triggering an autocatalyzed cell death pathway in Trichodesmium (Berman-Frank et al. 2004). P limitation did not determine the end of the growth phase, as similar biomasses were reached under P-replete as well as P-deplete conditions (Fig. 1). This might be due to luxury uptake of $\mathrm{P}$ and/ or the use of phosphonates when inorganic $\mathrm{P}$ became scarce (Dyhrman et al. 2006).

During bloom development, the DIC drawdown by photosynthetic carbon uptake exceeds the slow reequilibration with the atmosphere, causing chemical speciation of the DIC pool to shift toward higher $\mathrm{CO}_{3}^{2-}$ concentration and $\mathrm{pH}$. Upper $\mathrm{pH}$ values in our study are comparable to those observed during phytoplankton blooms (Hansen 2002), but such data on Trichodesmium blooms are scarce. Satpathy et al. (2007) observed $\mathrm{pH}$ values of 8.3 within a Trichodesmium bloom, yet the biomass in this field study was orders of magnitude lower $\left(\sim 4 \times 10^{6}\right.$ cells $\left.\mathrm{L}^{-1}\right)$ than the one in our and other studies $\left(\sim 5.7 \times 10^{9}\right.$ cells L $^{-1}$; Suvapepun 1992). Next to the total biomass buildup, weather conditions and mixing will also determine the magnitude in carbonate chemistry shift. In calm and highly stratified waters, a large change in the carbonate system of the bulk seawater can be expected. The overall changes in carbonate chemistry due to photosynthetic carbon uptake are, however, largest in the close proximity of the cells, the diffusive boundary layer (Wolf-Gladrow et al. 1999; Ploug 2008).

The deviation in carbonate chemistry between cell surface and bulk critically depends on the $\mathrm{C}$ uptake rate as well as speciation and the surface-to-volume ratio (WolfGladrow and Riebesell 1997). Trichodesmium operates an efficient carbon-concentrating mechanism based primarily on direct $\mathrm{HCO}_{3}^{-}$uptake (Kranz et al. 2009). Because of high affinities for $\mathrm{HCO}_{3}^{-}$, Trichodesmium can maintain high rates of carbon uptake even at low DIC concentrations. As filaments of Trichodesmium tend to form aggregates, so-called puffs and tufts often being $>500 \mu \mathrm{m}$ in diameter (La Roche and Breitbarth 2005), the surface-tovolume ratio is significantly smaller than for single filaments. Both high rates of $\mathrm{C}$ uptake in combination with the large size of aggregates imply that carbonate chemistry at the cell surface largely deviates from the situation in bulk water. To assess the magnitude of these 

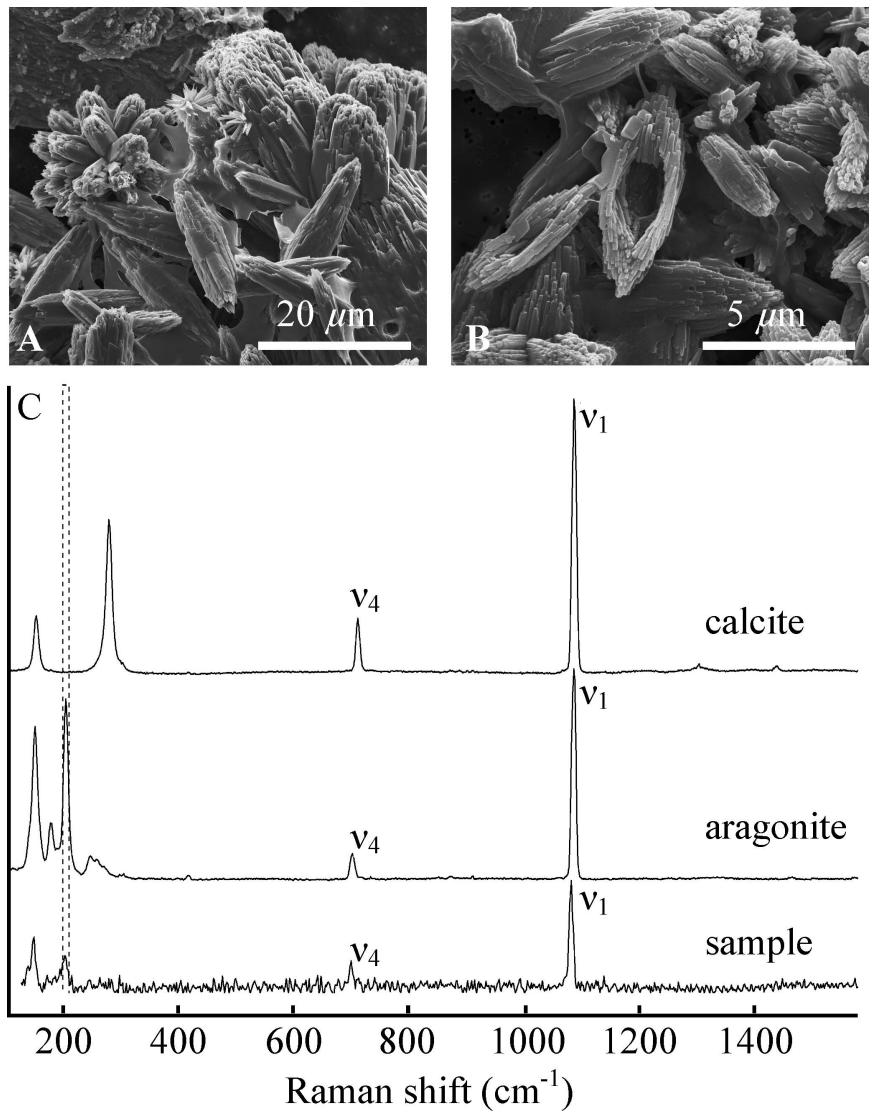

Fig. 3. (A, B) SEM pictures and (C) Raman spectra of the precipitate found in the P-deplete cultures. (A, B) Precipitates show needle type aragonitic crystals. Size bars are given in the picture. (C) Raman spectra of reference material (calcite, aragonite) and the sample. Calcite and aragonite both show a strong peak at $\sim 153 \mathrm{~cm}^{-1}\left(155 \mathrm{~cm}^{-1}\right.$ calcite and $152 \mathrm{~cm}^{-1}$ aragonite) but show unique peaks at $282 \mathrm{~cm}^{-1}$ (calcite) and $206 \mathrm{~cm}^{-1}$ (aragonite), using the lattice vibrations between 100 and $400 \mathrm{~cm}^{-1}$ wave numbers. Raman spectra were determined at 20 different positions chosen randomly across the crystal and showed no other carbonate phase than aragonite to be present.

differences, a diffusion-reaction model was applied. The calculated $\mathrm{pH}$ and $\Omega_{\mathrm{Ar}}$ at the aggregate surface was significantly higher than for the bulk media (Fig. 4). This finding supports our hypothesis that in blooms of Trichodesmium, which are often dominated by aggregates (Taboada et al. 2010), the effect on carbonate chemistry at the cell surface is comparable to or even more pronounced than in our study, where no aggregation occurred (Fig. 2).

This is the first study reporting the capability of the filamentous cyanobacterium Trichodesmium to induce $\mathrm{CaCO}_{3}$ formation, which was clearly reflected by the drop in TA in the P-deplete culture (Fig. 2B). Further analysis by Raman spectroscopy identified the precipitate as aragonite (Fig. 3C). As discussed previously, the photosynthetic activity of Trichodesmium can shift the carbonate system toward high $\mathrm{pH}$ and $\Omega_{\mathrm{Ar}}$ within the bulk and even further in the boundary layer. The increase in $\Omega_{\mathrm{Ar}}$ to values as high as $\sim 10$ (Fig. 2D) likely triggers the aragonite formation observed. As $\mathrm{CaCO}_{3}$ precipitation by cyanobac-

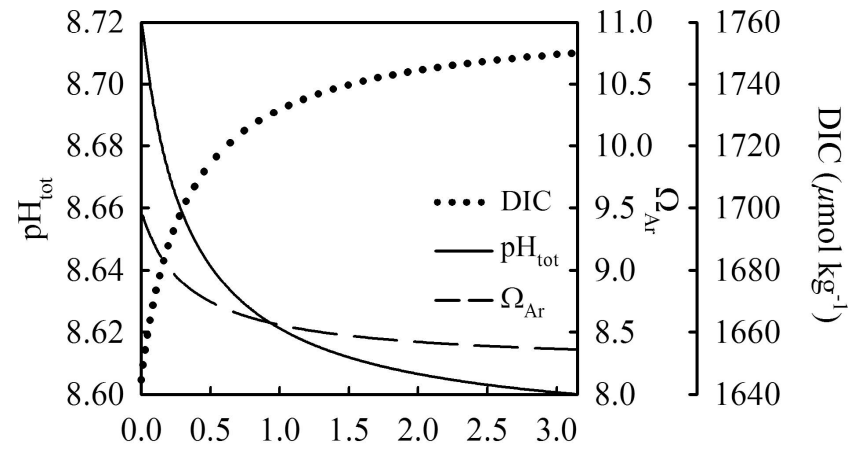

distance from aggregate surface $(\mathrm{mm})$

Fig. 4. Modeled profiles of DIC, $\mathrm{pH}$, and $\Omega_{\mathrm{Ar}}$ for a Trichodesmium aggregate as a function of the distance from the surface of the aggregate. Model input parameter for the bulk conditions were taken from day 13 of the P-deplete culture. Dotted line denotes DIC, solid line $\mathrm{pH}_{\mathrm{tot}}$, and dashed line $\Omega_{\mathrm{Ar}}$.

teria occurs at the cell sheath (Dittrich et al. 2003; Obst et al. 2009), it is strongly influenced by ambient conditions and thus, despite high supersaturation with respect to aragonite, may be hindered by interfering ions like $\mathrm{PO}_{4}^{3-}$ (House 1987; Lin and Singer 2005). This may explain why no aragonite precipitation occurred in the P-replete cultures. Consequently, late bloom situations with typically high $\Omega_{\mathrm{Ar}}$ and low $\mathrm{PO}_{4}^{3-}$ concentrations, like in our study (Figs. 1B, 2D), favor the precipitation of aragonite. Additionally, cyanobacteria are known to produce extracellular polymers (TEP), which can act as a binding site for $\mathrm{Ca}^{2+}$ and $\mathrm{CO}_{3}^{2-}$ (Thompson and Ferris 1990; SchultzeLam et al. 1992; Dittrich and Siebler 2010). As TEP production by Trichodesmium is induced by phosphorus depletion at the end of a bloom (Berman-Frank et al. 2007), that is, when aragonite precipitation was observed in our study, high concentrations of TEP may have contributed to the aragonite precipitation. For the freshwater cyanobacteria Synechococcus, experiments by Dittrich et al. (2003) showed that cell surface properties as well as the carbonate chemistry in the boundary layer determine whether $\mathrm{CaCO}_{3}$ is formed. The ability to precipitate $\mathrm{CaCO}_{3}$ therefore seems to be more widespread among cyanobacteria and follow similar mechanisms.

The importance of cyanobacteria-induced calcification in biogeochemical cycling has differed strongly over geological times and ecosystems. While in the limnic system calcification by cyanobacteria is quite common, calcification by marine planktonic cyanobacteria has rarely been studied. In the early Neoproteozoic (about 750-700 million years ago), however, immense carbonate sediments were produced by the marine filamentous cyanobacterium Girvanella (Riding 2006). In the Paleozoic and Mesozoic (between 550 million and 80 million years ago), several $\mathrm{CaCO}_{3}$ precipitation events were triggered by a diverse cyanobacterial flora (Riding 2006). In the early Cenozoic (about 50 million years ago), calcification events by cyanobacteria became scarce and thus less important for sediment formation (Riding 2006). It was proposed that the oceanic carbonate chemistry over the Cenozoic changed, 
making calcification by cyanobacteria less favorable (Riding 1982; Pentecost and Riding 1986). Nonetheless, there are indications for calcification events associated to cyanobacteria appearance in present-day marine systems, such as at the Great Bahama Bank (Robbins et al. 1996, 1997), where Trichodesmium also occurs (Carpenter et al. 1987). Field observations are needed to verify the potential of Trichodesmium to induce $\mathrm{CaCO}_{3}$ precipitation and to predict possible implications for biogeochemical cycling.

\section{Acknowledgments}

We thank Klaus-Uwe Richter and Ulrike Richter for laboratory assistance and two anonymous reviewers for constructive comments on the manuscript. The research leading to these results has received funding from the European Research Council (ERC) under the European Community's Seventh Framework Programme (FP7/2007-2013)/ERC grant agreement (205150 to B.R.). Financial support was also provided by the Federal Ministry of Education and Research (Bundesministerium für Bildung und Forschung, grant no. 03F0608 A03F0608B to G.N.). This research contributes to the "European Project on Ocean Acidification" under grant agreement 211384 and to the BMBFfunded project "Biological Impacts of Ocean Acidification." G.L. acknowledges financial support by the Spanish Ministry of Education (Juan de la Cierva program) cofunded by the European Social Fund and Ministry of Science and Innovation.

\section{References}

Anders Ohlsson, K. E., and P. H. Wallmark. 1999. Novel calibration with correction for drift and non-linear response for continuous flow isotope ratio mass spectrometry applied to the determination of $\delta^{15} \mathrm{~N}$, total nitrogen, $\delta^{13} \mathrm{C}$ and total carbon in biological material. Analyst 124: 571-577, doi:10.1039/a900855a

Arrigo, K. R., D. H. Robinson, D. L. Worthen, R. B. Dunbar, G. R. Ditullio, M. Vanwoert, and M. P. Lizotte. 1999. Phytoplankton community structure and the drawdown of nutrients and $\mathrm{CO}_{2}$ in the Southern Ocean. Science 283: 365-367, doi:10.1126/science. 283.5400.365

Behrens, G., L. T. Kuhn, R. Ubic, and A. H. Heuer. 1995. Raman spectra of vateritic calcium carbonate. Spectrosc. Lett. 28: 983-995, doi:10.1080/00387019508009934

Berman-Frank, I., K. D. Bidle, L. Haramaty, and P. G. FALKOWSKi. 2004. The demise of the marine cyanobacterium, Trichodesmium spp., via an autocatalyzed cell death pathway. Limnol. Oceanogr. 49: 997-1005, doi:10.4319/1o.2004.49. 4.0997

, G. Rosenberg, O. Levitan, L. Haramaty, and X. Mari. 2007. Coupling between autocatalytic cell death and transparent exopolymeric particle production in the marine cyanobacterium Trichodesmium. Environ. Microbiol. 9: 1415-1422, doi:10.1111/j.1462-2920.2007.01257.x

Capone, D. G., and E. J. Carpenter. 1982. Nitrogen fixation in the marine environment. Science 217: 1140-1142, doi:10.1126/ science. 217.4565 .1140

_ AND OTHERS. 2005. Nitrogen fixation by Trichodesmium spp.: An important source of new nitrogen to the tropical and subtropical North Atlantic Ocean. Glob. Biogeochem Cycles 19: GB2024, doi:2010.1029/2004GB002331

Carpenter, E. J., M. I. Scranton, P. C. Novelli, and A. MichaELs. 1987. Validity of $\mathrm{N}_{2}$ fixation rate measurements in marine Oscillatoria (Trichodesmium). J. Plankton Res. 9: 1047-1056, doi:10.1093/plankt/9.6.1047
Chen, Y.-B., J. P. Zehr, and M. Mellon. 1996. Growth and nitrogen fixation of the diazotrophic filamentous nonheterocystous cyanobacterium Trichodesmium sp. IMS 101 in defined media: Evidence for a circadian rhythm. J. Phycol. 32: 916-923, doi:10.1111/j.0022-3646.1996.00916.x

Des Marais, D. J. 2000. Evolution: When did photosynthesis emerge on Earth? Science 289: 1703-1705.

Dickson, A. G., And F. J. Millero. 1987. A comparison of the equilibrium constants for the dissociation of carbonic acid in seawater media. Deep-Sea Res. 34: 1733-1743.

Dittrich, M., B. Müller, D. Mavrocordatos, and B. Wehrli. 2003. Induced calcite precipitation by cyanobacterium Synechococcus. Acta Hydrochim. Hydrobiol. 31: 162-169.

—, AND S. Siebler. 2010. Calcium carbonate precipitation by cyanobacterial polysaccharides. Geol. Soc. Lond. Spec. Publ. 336: 51-63, doi:10.1144/SP336.4

Dyhrman, S. T., P. D. Chappell, S. T. Haley, J. W. Moffett, E. D. Orchard, J. B. Waterbury, and E. A. Webb. 2006. Phosphonate utilization by the globally important marine diazotroph Trichodesmium. Nature 439: 68-71, doi:10.1038/ nature 04203

Gianesella-Galvao, S. M. F., M. P. F. Costa, and M. B. KutNer. 1995. Bloom de Oscillatoria (Trichodesmium) erythraea (Ehr.) Kutz. in coastal waters of the Southwest Atlantic. Publ. Esp. Inst. Oceonograf. 11: 133-140.

Gran, G. 1952. Determination of the equivalence point in potentiometric titrations, part II. The Analyst 77: 661-671, doi:10.1039/an9527700661

Hansen, P. J. 2002. Effect of high $\mathrm{pH}$ on the growth and survival of marine phytoplankton: implications for species succession. Aquat. Microb. Ecol. 28: 279-288, doi:10.3354/ ame 028279

—, N. Lundholm, And B. Rost. 2007. Growth limitation in marine red-tide dinoflagellates: Effects of $\mathrm{pH}$ versus inorganic carbon availability. Mar. Ecol. Prog. Ser. 334: 63-71, doi:10.3354/meps334063

Holligan, P. M., And others. 1993. A biogeochemical study of the coccolithophore, Emiliania huxleyi, in the North-Atlantic. Glob. Biogeochem. Cycles 7: 879-900, doi:10.1029/ 93GB01731

House, W. A. 1987. Inhibition of calcite crystal growth by inorganic phosphate. J. Coll. Interf. Sci. 119: 505-511, doi:10.1016/0021-9797(87)90296-7

Kranz, S. A., D. Sueltemeyer, K.-U. Richter, and B. Rost. 2009. Carbon acquisition in Trichodesmium: The effect of $p \mathrm{CO}_{2}$ and diurnal changes. Limnol. Oceanogr. 54: 548-559.

La Roche, J., and E. Breitbarth. 2005. Importance of the diazotrophs as a source of new nitrogen in the ocean. J. Sea Res. 53: 67-91, doi:10.1016/j.seares.2004.05.005

Lewis, E., And D. W. R. Wallace. 1998. Program developed for $\mathrm{CO}_{2}$ system calculations. ORNL/CDIAC-105. Oak Ridge (TN): Carbon Dioxide Information Analysis Center, Oak Ridge National Laboratory, US Department of Energy.

Lin, Y.-P., AND P. C. Singer. 2005. Inhibition of calcite crystal growth by polyphosphates. Water Res. 39: 4835-4843, doi:10.1016/j.watres.2005.10.003

Mehrbach, C., C. H. Culberson, J. E. Hawley, and R. M. Pyткоwicz. 1973. Measurement of the apparent dissociation constants of carbonic acid in seawater at atmospheric pressure. Limnol. Oceanogr. 18: 897-907, doi:10.4319/ lo.1973.18.6.0897

Mulholland, M. R., C. A. Heil, D. A. Bronk, and M. O. O'NeIL. 2006. Nitrogen fixation and release of fixed nitrogen by Trichodesmium sp. in the Gulf of Mexico. Limnol. Oceanogr. 51: 1762-1776, doi:10.4319/1o.2006.51.4.1762 
Obst, M., B. Wehrli, And M. Dittrich. 2009. $\mathrm{CaCO}_{3}$ nucleation by cyanobacteria: Laboratory evidence for a passive, surfaceinduced mechanism. Geobiology 7: 324-347, doi:10.1111/ j.1472-4669.2009.00200.x

Pentecost, A., And R. Riding. 1986. Calcification in cyanobacteria, p. 914-921. In B. S. C. Leadbeater and R. Riding [eds.], Biomineralization in lower plants and animals. Clarendon Press.

Ploug, H. 2008. Cyanobacterial surface blooms formed by Aphanizomenon sp. and Nodularia spumigena in the Baltic Sea: Small-scale fluxes, $\mathrm{pH}$, and oxygen microenvironments. Limnol. Oceanogr. 53: 914-921.

RIDING, R. 1982. Cyanophyte calcification and changes in ocean chemistry. Nature 299: 814-815, doi:10.1038/299814a0

. 2006. Cyanobacterial calcification, carbon dioxide concentrating mechanisms, and Proterozoic-Cambrian changes in atmospheric composition. Geobiology 4: 299-316, doi:10.1111/j.1472-4669.2006.00087.x

Robbins, L. L., Y. Tao, and C. A. Evans. 1997. Temporal and spatial distribution of whitings on Great Bahama Bank and a new lime mud budget. Geology 25: 947-950, doi:10.1130/ 0091-7613(1997)025<0947:TASDOW > 2.3.CO;2

, K. K. Yates, G. Shinn, and P. Blackwelder. 1996. Whiting on the great Bahama bank: A microscopic solution to a macroscopic mystery. Bahamas J. Sci. 4: 2-7.

Satpathy, K. K., A. K. Mohanty, G. Sahu, V. M. R. Prasad, R. Venkatesan, U. Natesan, and M. Rajan. 2007. On the occurrence of Trichodesmium erythraeum (Ehr.) bloom in the coastal waters of Kalpakkam, east coast of India. Indian J. Sci. Technol. 1: 1-9.

Schultze-Lam, S., G. Harauz, and T. J. Beveridge. 1992. Participation of a cyanobacterial S layer in fine-grain mineral formation. J. Bacteriol. 174: 7971-7981.

Siqueira, A., H. E. Kolm, and F. P. Brandini. 2006. Offshore distribution patterns of the cyanobacterium Trichodesmium erythraeum Ehrenberg and associated phyto- and bacterioplankton in the southern Atlantic coast (Paraná, Brazil). Braz. Arch. Biol. Technol. 49: 323-337.
Stoll, M. H. C., K. Bakker, G. H. Nobbe, and R. R. Haese. 2001. Continuous-flow analysis of dissolved inorganic carbon content in seawater. Anal. Chem. 73: 4111-4116, doi:10.1021/ ac010303r

Suvapepun, S. 1992. Trichodesmium blooms in the Gulf of Thailand, p. 343. In E. J. Carpenter, D. G. Capone, and J. G. Rueter [eds.], Marine pelagic cyanobacteria: Trichodesmium and other diazotrophs. Kluwer Academic.

Taboada, F. G., R. G. Gil, J. Hofer, S. Gonzalez, and R. AnADON. 2010. Trichodesmium spp. population structure in the eastern North Atlantic subtropical gyre. Deep-Sea Res. 57: $65-77$.

Thompson, J. B., AND F. G. Ferris. 1990. Cyanobacterial precipitation of gypsum, calcite, and magnesite from natural alkaline lake water. Geology 18: 995-998, doi:10.1130/00917613(1990)018<0995:CPOGCA > 2.3.CO;2

Wolf-Gladrow, D. A., J. Bijma, and R. E. Zeebe. 1999. Model simulation of the carbonate chemistry in the microenvironment of symbiont bearing foraminifera. Mar. Chem. 64: 181-198, doi:10.1016/S0304-4203(98)00074-7

—, AND U. Riebesell. 1997. Diffusion and reactions in the vicinity of plankton: A refined model for inorganic carbon transport. Mar. Chem. 59: 17-34, doi:10.1016/S0304-4203(97) 00069-8

Zeebe, R. E., And D. A. Wolf-Gladrow. 2007. $\mathrm{CO}_{2}$ in seawater: Equilibrium, kinetics, isotopes. Elsevier Science.

Associate editor: Heidi M. Sosik

Received: 12 March 2010

Accepted: 02 August 2010

Amended: 27 August 2010 